Study of the paraglycogen structure by classic methods such as determination of the wavelength of peak-absorption $(\lambda \mathrm{max})$ of its iodine complex, the average chain length $(\overline{\mathrm{Cl}})$, outer $(\overline{\mathrm{OCl}})$ and inner $(\overline{\mathrm{ICl}})$ chains by periodic oxidation and the $\beta$-amylolysis rale also lead to the amylopectin type.

However it must be noted that these different determinations are all mean values based on the individual value of the members of a population of molecules which can vary strongly in their structure and their chain length.

The recent discovery of specific enzymes of $\alpha \mathrm{I} \rightarrow 6$ branch linkages in a $\alpha$-glucans, pullulanase (Bender and Wallenfels, 196r) and isoamylase (Gunja-Smith, Marshale, Smith and WhELAN, 1970) has permitted us to develop an enzymic method to study the fine structure of $\alpha$-glucans (MeRCIER and WHELAN, I970). The latter, in contrast with the classic methods, has the advantage of debranching the constitutive chains of the $\alpha$-glucan without any degradation and of allowing the study of their distribution in terms of chain length and number, after fractionating them on Sephadex G-5o.

Thus, submitted to the successive action of pullulanase, isoamylase, $\beta$-amylase, amyloglucosidase and glucose-oxidase, the fine structure of paraglycogen of Gregarina blaberae has been compared to that of rabbit-liver glycogen and plant amylopectin (MERCIER, SCHREVEL and STARK, I973).

Although the results obtained by the classic methods indicate an amylopectin structure, the distribution of constitutive chains of paraglycogen is different from those of glycogen and amylopectin, conferring a structure between these two last ones and similar to that of sweet corn phytoglycogen.

\title{
ÉVOLUTION DE LA MICROFLORE DIGESTIVE DU LAPIN HOLOXÉniQUE DE LA NAISSANCE AU SEVRAgE
}

\author{
$\mathrm{Ph}$. GOUET et G. FONTY \\ Laboratoire de Microbiologie, \\ Centre de Recherches de Clermont Ferrand, I. N. R. A., \\ Theix 63110 Beaumont
}

Nous avons dénombré chez des lapins holoxéniques (conventionnels) nourris avec un aliment lapin, âgés de $7,14,2 \mathrm{I}, 28,42$ et 56 jours, les bactéries cultivables en anaérobiose aux niveaux de l'estomac, de l'intestin grêle, du cæcum et du côlon. La technique anaérobie employée a été celle préconisée par HUNGate. Nous avons ensuite caractérisé les souches isolées de la microflore dominante pour chacun des organes considérés. Les résultats obtenus sont les suivants :

- La vitesse de colonisation de l'estomac, irrégulière, est tributaire de variations individuelles importantes. Le nombre total de bactéries est généralement faible; il tend à augmenter avec l'âge et se stabilise après sevrage entre $10^{4}$ et $10^{6}$ bactéries/gramme de contenu.

- Dans l'intestin grêle l'implantation des bactéries est plus rapide et plus abondante que dans l'estomac. L'amplitude des variations individuelles, importante chez les jeunes lapereaux, s'estompe après sevrage et la microflore se stabilise entre $5.10^{6}$ et $10^{8}$ bactéries/gramme.

- Le cæcum héberge dès la première semaine, une flore abondante $\left(\mathrm{I}^{7}-\mathrm{IO}^{9} / \mathrm{g}\right)$; par la suite, le nombre de bactéries est constamment élevé $\left({ }^{2} \mathrm{O}^{9}-\mathrm{IO}^{10} / \mathrm{g}\right)$ et varie peu suivant $\mathrm{l}^{\prime}$ âge et les échantillons. 
- La microflore du côlon suit une évolution identique à celle đu cæcum mais le nombre de bactéries dénombrées y est légèrement plus faible.

La microflore du lapin est caractérisée par la dominance d'espèces anaérobies strictes et particulièrement de bacille Gram négatif non sporulés (Bactéroỉdes) que l'on retrouve à tous les niveaux du tube digestif. Ce phénomène est sans doute en liaison avec la coprophagie de l'animal. Les Lactobacilles sont toujours absents du tube digestif du lapin, ce qui constitue une exception notable parmi les rongeurs étudiés. Il faut enfin souligner que les Entérobactéries sont généralement absentes chez les jeunes lapereaux; elles apparaissent et atteignent un maximum (Io $7 \mathrm{~g}$ ) au moment du sevrage ( 2 I jours) puis diminuent rapidement ensuite et se stabilisent vers $10^{4} / \mathrm{g}$.

Les Streptocoques sont presque toujours absents de l'estomac des lapereaux de 7 jours, alors qu'il sont régulièrement présents dans l'intestin grêle, le cæcum et le côlon en nombres élevés atteignant le niveau de la microflore dominante. Leur présence est plus irrégulière à partir de la $2^{\mathrm{e}}$ semaine et, après sevrage, ils disparaissent de l'intestin grêle et se situent entre $\mathrm{Io}^{2}$ et ${ }^{1} \mathrm{O}^{4} / \mathrm{g}$ dans le cæcum et le côlon. Les Clostridium n'apparaissent qu'après sevrage et seulement dans le cæcum et le côlon $\left(10^{3}-\mathrm{IO}^{5} / \mathrm{g}\right)$.

Bien que cette étude soit encore incomplète on peut déjà conclure que le lapin possède une microflore très originale du fait de son caractère anaérobie strict dominant, de l'absence de Lactobacilles, du faible peuplement de l'estomac malgré la coprophagie.

\section{SUMMARY}

\section{EVOLUTION OF THE INTESTINAL MICROFLORA OF CONVENTIONAL RABBITS FROM BIRTH TO WEANING}

Using $7, \mathbf{1} 4,2 \mathbf{1}, 28,42$ and 56 days old holoxenic (conventional) rabbits fed usual diets, we counted the number of bacteria from the stomach, small gut, crecum and colon that could be cultivated in anaerobiosis. The anaerobic technique used was that preconized by HunGate. The strains isolated from the dominating microflora of each organ considered were characterized. The results obtained were the following:

- The irregular colonization rate of the stomach depends on large individual variations. The total number of bacteria is generally low; it tends to increase with age and stabilizes after weaning between $10^{4}$ and $10^{6}$ bacteria/g of content.

- The implantation of bacteria is faster and more abundant in the small gut than in the stomach. The magnitude of the individual variations, which is great in young rabbits, decreases after weaning and the microflora stabilizes between $5 \cdot 10^{6}$ and $10^{8}$ bacteria $/ \mathrm{g}$.

- The cacum contains from the first week an abundant flora (107-10\% $/ \mathrm{g}$ ); thereafter the number of bacteria constantly increases $\left(\mathrm{IO}^{9}-\mathrm{IO}^{10} / \mathrm{g}\right)$. and varies little according to age and samples.

- The microflora development in the colon is identical to that of the cacum, but the number of bacteria is slightly smaller.

The microflora of the rabbit is characterized by the dominance of strict anaerobic species and especially by non sporulated Gram negative bacilli (Bacteroïdes) that can be observed at all levels of the digestive tract. This phenomenon is probably related to the coprophagy of the animal. The Lactobacilli are always absent in the digestive tract of the rabbit, a fact that constitutes a notable exception among the rodents studied. Finally, it has to be emphasized that Enterobacteria are generally absent in young rabbits; they appear and reach a maximum (Io $/ \mathrm{g}$ ) at the moment of weaning ( $2 \mathrm{r}$ days), then decrease rapidly and stabilize about $\mathrm{ro}^{4} / \mathrm{g}$.

Streptococci are nearly always absent in the stomach of 7 days old rabbits, whereas in the small gut, cæcum, colon they are regularly present in a great number attaining the level of the 
dominatin $\gamma$ microflora. Their presence is more irregular from the and week and, after weaning they disappear from the small gut and show a level between $10^{2}$ and $10^{4} / \mathrm{g}$ in the cæcum and colon. The Clostridia only appear after weaning and exclusively in the cæcum and colon $\left(10^{3}-10^{5} / g\right)$.

Although this study is still incomplete it can already be concluded that the rabbit has a very original microflora because of its dominating strict anaerobic character, the absence of Lactobacilli, and the low population density in the stomach despite the coprophagy.

\title{
URÉOLYSE PAR DIFFÉRENTES BAGTÉRIES « IN VITRO » ET « IN VIVO » DANS LE TUBE DIGESTIF DE RATS « GNOTOXÉNIQUES ». INFLUENCE DE L'IMMUNISATION
}

\author{
Marie-Christiane MOREAU, R. DUCLUZEAU et P. RAIBAUD \\ Labovatoire d'Écologie microbienne, \\ Centre national de Recherches zootechniques, $I$. N. R. A., \\ 78350 Jouy en Josas
}

Le rat axénique excrète dans ses fèces environ $40 \mathrm{mg}$ d'urée pour roo $\mathrm{g}$ de fèces fraîches alors qu'on ne trouve pas d'urée dans les fèces d'animaux holoxéniques. Nous avons donc cherché à savoir quelles étaient les souches bactériennes présentes dans le tube digestif des holoxéniques qui sont responsables de cette uréolyse. Par ailleurs, nous avons essayé de modifier cette activité uréolytique par des moyens immunologiques.

I $^{\circ}$ On a isolé du tube digestif de rats holoxéniques une souche de Lactobacillus et une souche d'Actinobacillus qui sont uréolytiques in vitro. On ensemence le tube digestif de rats axéniques avec chacune de ces 2 souches, et on suit la cinétique d'hydrolyse de l'urée dans leurs fèces.

Chez le rat monoxénique hébergeant l'Actinobacillus, l'uréolyse débute dans les fèces en même temps qu'apparaissent les premières bactéries, soit 6 heures après l'ensemencement de la souche et elle est totale 4 heures plus tard, alors que la population bactérienne a atteint son maximum, soit 5. IO $^{B}$ bactéries/g de fèces fraîches.

Chez le rat monoxénique hébergeant le Lactobacillus, les premières bactéries apparaissent 6 heures après l'ensemencement, la population atteint son maximum, soit $10^{9}$ bactéries/g de fèces fraîches, 2 heures plus tard, mais l'uréolyse ne débute que 12 heures après l'ensemencement pour atteindre son maximum 9 heures plus tard.

Le dosage de l'urée dans les différents compartiments du tube digestif des deux types de rats monoxéniques montre qu'il reste toujours de l'urée dans l'estomac et l'intestin grêle, alors que l'uréolyse devient totale à partir du cæeum.

In vitro, l'hydrolyse de l'urée s'observe seulement à la fin de la croissance chez le Lactobacillus, alors qu'elle commence dès le début de la croissance chez l'Actinobacillus. Les $\mathrm{pH}$ optimum d'action des uréases de ces 2 bactéries sont très différentes : 6,0 pour l'uréase de l'Actinobacillus et 2,5 à 3,0 pour l'uréase du Lactobacillus. On peut penser que ces bactéries exercent leur effet uréolytique à des niveaux différents du tube digestif : estomac pour le Lactobacillus et cæcum pour l'Actinobacillus.

$2^{\circ}$ Des rats porteurs d'une monoflore de Lactobacillus uréolytiques sont immunisés avec différents types d'antigènes. Si on les vaccine avec une suspension des mêmes bactéries qu'ils hébergent, ou avec un extrait protéique total de ces bactéries, on peut observer l'apparition dans les fèces et le cæcum des animaux d'une concentration d'urée qui est, dans certains cas, 